\title{
Multi-isotope (carbon and chlorine) analysis for fingerprinting and site characterization at a fractured bedrock aquifer contaminated by chlorinated ethenes
}

Jordi Palau a,*, Massimo Marchesi a,b, Julie C.C. Chambon ${ }^{\mathrm{c}}$, Ramon Aravena ${ }^{\mathrm{b}}$, Àngels Canals ${ }^{\mathrm{a}}$, Philip J. Binning c, Poul L. Bjerg ${ }^{c}$, Neus Otero ${ }^{a}$, Albert Soler ${ }^{a}$

a Departament de Cristal.lografia, Mineralogia i Dipòsits Minerals, Facultat de Geologia, Universitat de Barcelona, Martí i Franquès, s/n 08028 Barcelona, Spain

b Department of Earth and Environmental Sciences, University of Waterloo, Waterloo, Ontario N2L 3G1, Canada

c Department of Environmental Engineering, Technical University of Denmark, 2800 Lyngby, Denmark

\section{H I G H L I G H T S}

- Origin and fate of CAHs in groundwater by means of multi CSIA $\left({ }^{13} \mathrm{C},{ }^{35} \mathrm{Cl}\right)$ survey

- Innovative/new approach tested in a fractured bedrock site

- Differentiation of distinct CAH sources

- Biodegradation and source mixing recognition in the aquifer

\section{A R T I C L E I N F O}

\section{Article history:}

Received 20 October 2013

Received in revised form 13 December 2013

Accepted 14 December 2013

Available online 11 January 2014

\section{Keywords:}

Compound-specific isotope analysis

Groundwater contamination

Environmental forensics

Chlorinated solvents

\author{
G R A P H I C A L A B S T R A C T
}

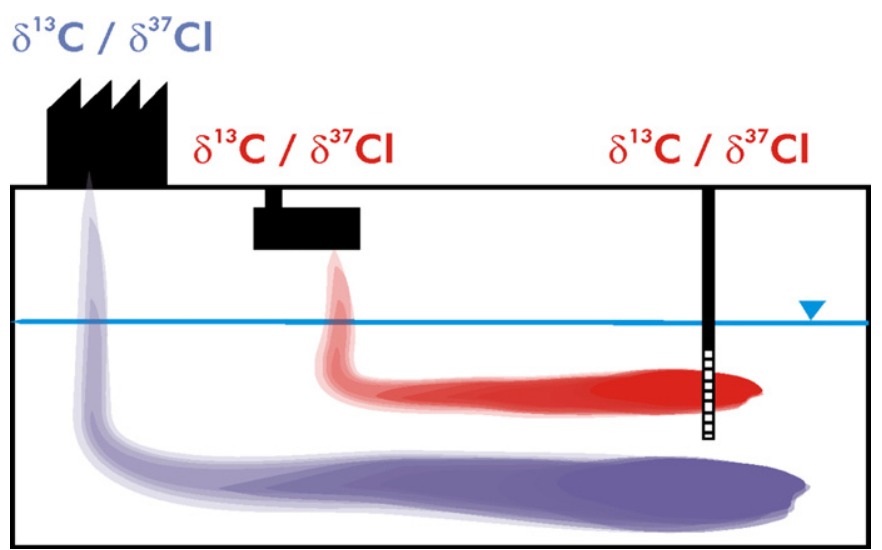

\section{A B S T R A C T}

The use of compound specific multi-isotope approach $(\mathrm{C}$ and $\mathrm{Cl})$ in the characterization of a chlorinated ethenes contaminated fractured aquifer allows the identification of several sources and contaminant plumes, as well as the occurrence of biodegradation and mixing processes. The study site is located in Spain with contamination resulting in groundwater concentrations of up to $50 \mathrm{mg} / \mathrm{L}$ of trichloroethene (TCE), the most abundant chlorinated ethene, and $7 \mathrm{mg} / \mathrm{L}$ of tetrachloroethene (PCE). The potential sources of contamination including abandoned barrels, an underground tank, and a disposal lagoon, showed a wide range in $\delta^{13} \mathrm{C}$ values from -15.6 to $-40.5 \%$ for TCE and from -18.5 to $-32.4 \%$ for PCE, allowing the use of isotope fingerprinting for tracing of the origin and migration of these contaminants in the aquifer. In contrast, there is no difference between the $\delta^{37} \mathrm{Cl}$ values for TCE in the contaminant sources, ranging from +0.53 to $+0.66 \%$. Variations of $\delta^{37} \mathrm{Cl}$ and $\delta^{13} \mathrm{C}$ in the different contaminant plumes were used to investigate the role of biodegradation in groundwater. Moreover, the isotopic data were incorporated into a reactive transport model for determination of whether the isotope pattern observed downstream from the tank's source could be explained by the simultaneous effect of mixing and biodegradation. The results demonstrate that a multi-isotope approach is a valuable tool for

\footnotetext{
* Corresponding author at: Centre d'hydrogéologie et de géothermie, Université de Neuchâtel, Rue Emile-Argand 11, Neuchâtel 2000, Switzerland.

E-mail address: jordi.palau@unine.ch (J. Palau).
} 
characterization of complex sites such as fractured bedrock aquifer contaminated by multiple sources, providing important information which can be used by consultants and site managers to prioritize and design more successful remediation strategies.

(C) 2013 Elsevier B.V. All rights reserved.

\section{Introduction}

Chlorinated aliphatic hydrocarbons such as TCE and PCE are among the most widespread contaminants in soil and groundwater as they are commonly used as solvents in heavy industries and dry cleaning facilities (Squillace et al., 1999). These compounds can migrate over long distances in aquifers and can also be degraded under specific conditions (Pankow and Cherry, 1996; Wiedemeier, 1999). The potential degradation along the flow path and the fact that there often are multiple sources of contaminants produce complex plumes of dissolved chlorinated solvents and degradation products, such as cis-1,2dichloroethene ( $\mathrm{CDCE}$ ) and vinyl chloride (VC), which are difficult to trace. This phenomenon may be amplified in fractured aquifers, where fractures complicate the prediction of the contamination extent (Vroblesky et al., 1996). Consultants and site managers at contaminated sites might want to assess the impact of different sources and link them to downstream contamination in order to prioritize remediation strategies; for example, by treating particular sources or plumes to minimize the risk to the environment and potential receptors and to set remediation goals.

The rationale for using compound specific isotope analysis (CSIA) in environmental forensic studies is based on the wide isotopic composition $\left(\delta^{13} \mathrm{C}\right.$, but also $\left.\delta^{37} \mathrm{Cl}\right)$ range of manufactured chlorinated compounds (Jendrzejewski et al., 2001; Numata et al., 2002; ShouakarStash et al., 2003). During recent years, compound specific carbon isotope analysis has been used to fingerprint sources of chlorinated solvents and trace their migration in groundwater (Blessing et al., 2009; Hunkeler and Aravena, 2010). Recently, the development of CSIA for chlorine isotopes (Aeppli et al., 2010; Bernstein et al., 2011; Sakaguchi-Soder et al., 2007; Shouakar-Stash et al., 2006; Van Acker et al., 2006) enables a multi-isotope approach.

Isotopic fingerprinting of chlorinated ethenes can even be used on old contaminated sites because of the small or insignificant changes in the isotopic signature occurring during phase transfer processes such as dissolution, sorption, and volatilization (Braeckevelt et al., 2012; Hunkeler et al., 2004; Poulson and Drever, 1999; Slater et al., 2000; Thullner et al., 2012). Recently, chlorine isotopic fractionation was determined to be small for dissolved PCE and TCE during air-water partitioning $\left(\varepsilon_{\mathrm{Cl}}=-0.20 \pm 0.04 \%\right.$ and $-0.06 \pm 0.05 \%$ o respectively $)$ (Jeannottat and Hunkeler, 2012, 2013) resulting in negligible variations of $\delta^{37} \mathrm{Cl}$ in the saturated zone (Braeckevelt et al., 2012). Moreover, contaminant removal due to volatilization from groundwater is low in many aquifers under natural conditions (Thullner et al., 2012). In contrast, substantial isotopic fractionation leading to progressive enrichment in carbon and chlorine heavy isotope is produced during abiotic or biotic degradation (Abe et al., 2009; Audí-Miró et al., 2013; Hunkeler et al., 2011; Lojkasek-Lima et al., 2012a,b; Wiegert et al., 2013). By the combined use of isotope data for two elements - chlorine and carbon for chlorinated solvents - it may be possible to identify different sources even if they contain the same contaminants and are subject to ongoing degradation processes (Hunkeler et al., 2009; LojkasekLima et al., 2012a). Furthermore, additional information about plume mixing in complicated groundwater flow systems such as fractured aquifers may be obtained using a multi-isotope approach. Several authors have recently employed reactive transport models to help analyse isotope data and quantify degradation and fate of chlorinated solvents at complex field sites (Hohener and Atteia, 2010; Pooley et al., 2009; Van Breukelen et al., 2005; Wiegert et al., 2012). This approach is essential to interpret isotopic values of parent and degradation compounds at sites where sequential degradation occurs (Van Breukelen et al., 2005; Wiegert et al., 2012).

To date, field studies including CSIA of carbon and chlorine are scarce in the literature and this approach has not yet been applied to link sources and plumes in contaminated sites where several sources are present. Our study investigates the origin and fate of chlorinated ethenes in a fractured bedrock site impacted by different sources using compound-specific carbon and chlorine isotope analysis and reactive transport modelling. The characterization of redox conditions of the aquifer was based on concentrations of redox sensitive compounds. The isotope signatures of the potential sources were determined and compared with the manufacturers' reported range. Our goals were (i) to characterize the chlorinated ethenes plumes and to relate them to their sources even when parent compounds experience biodegradation, and (ii) to combine carbon and chlorine isotope data with numerical modelling to identify the occurrence of biodegradation and mixing processes.

\section{Methods}

\subsection{Site description}

The studied aquifer is located $50 \mathrm{~km}$ northwest of Barcelona (NE Spain). The contamination originated from a former chemical plant, where TCE and PCE were used as chemical intermediates for the manufacture of phytosanitary products and chemical compounds for the textile industry between 1978 and 1985 . The site is highly complex due to the presence of multiple contaminant sources of chlorinated solvents: 1) an underground wastewater tank, 2) a disposal lagoon and 3) abandoned solvent barrels inside the manufacturing building (Fig. 1). It is probable that some barrels were filled with waste solvent. Moreover, several spills detected around the plant building were also potential sources of contamination. The disposal lagoon was emptied and refilled with sand and gravel prior to the closure of the manufacturing facility, while the tank remained partially full.

The aquifer is an unconfined fractured bedrock mainly consisting of an Eocene blue-grey limestone bed which forms a low permeability matrix with conductive fractures and fissures (Fig. 1). The water table is located at depths ranging between 3.2 and $11.7 \mathrm{~m}$ below ground surface (BGS). The hydraulic conductivity, estimated with pumping tests at the site, is highly variable ranging from $1.44 \times 10^{-3}$ to $0.6 \mathrm{~m} /$ day (Table S1 in supplementary information (SI)). The hydraulic gradient has shown significant seasonal variation and an average value of approximately $10 \%$ (Fig. 1 ). More details about the contaminant sources, subsurface geology, and the aquifer are available in the SI (Section 1).

\subsection{Sample collection}

Groundwater samples for plume characterization were collected (mostly in March 2006) from ten multilevel nested wells leading to a total of 147 sampling points. The use of multilevel samplers helps in avoiding groundwater mixing in sampling wells as samples from long screen monitoring wells are generally a mixture of contaminants from different parts of the plume with varying degrees of degradation, isotope values and redox conditions, complicating data interpretation. Eh, $\mathrm{pH}$, dissolved oxygen (DO) and temperature were measured in situ and samples for dissolved organic carbon (DOC) were collected from all sampling points. Samples for other parameters were obtained from selected depths: 86 samples for volatile organic compounds 

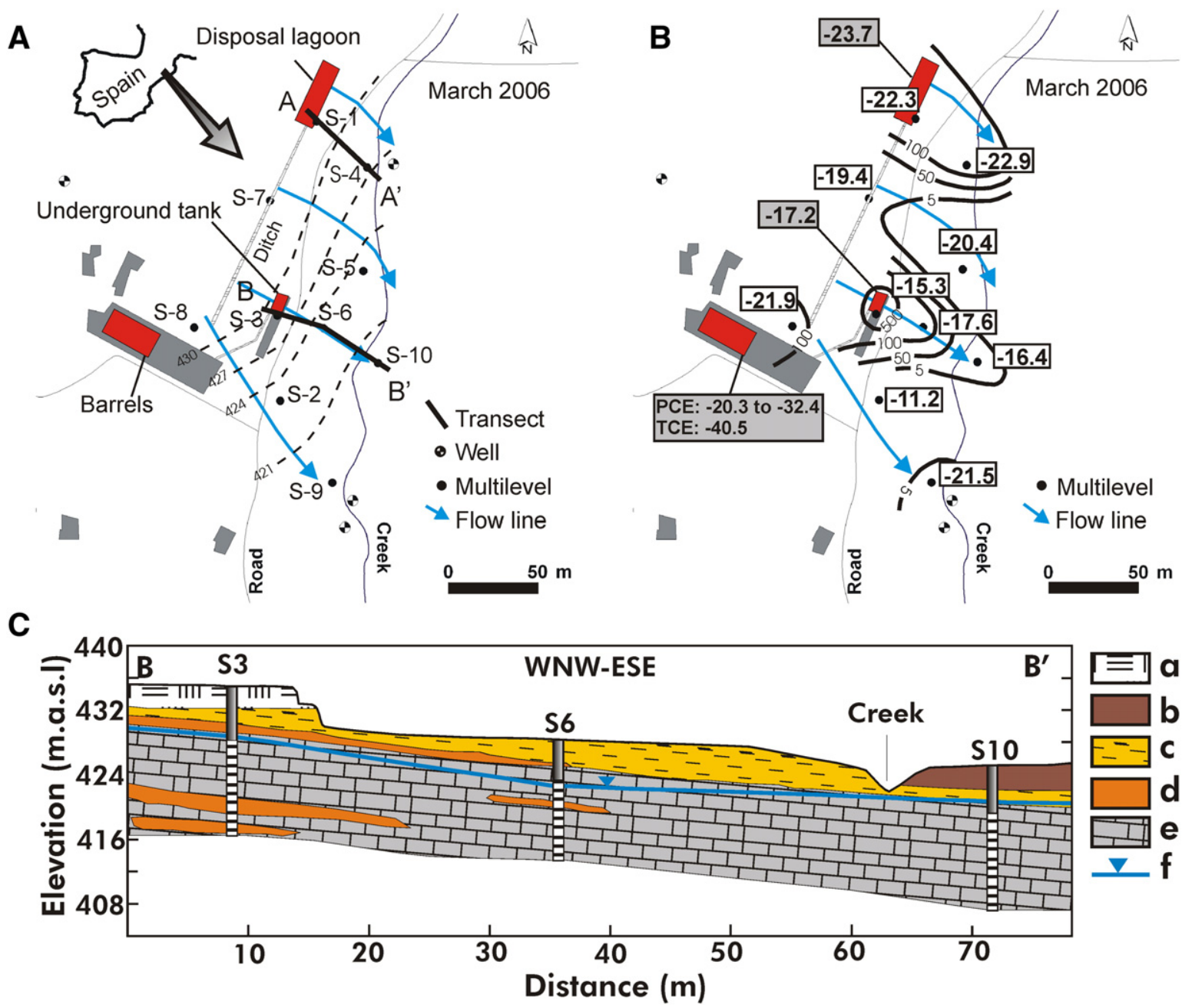

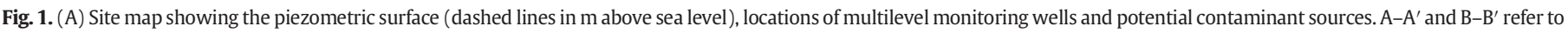

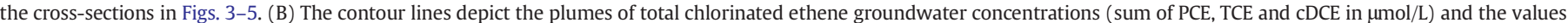

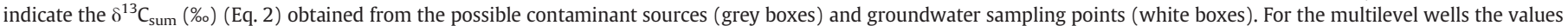

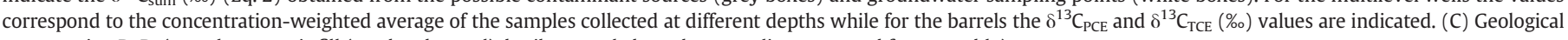
cross-section B-B' (a. anthropogenic fill (sand and gravel), b. silt, c. marl, d. sandstone, e. limestone and f. water table).

(VOC), 23 for redox sensitive compounds $\left(\mathrm{NO}_{3}^{-}, \mathrm{NO}_{2}^{-}\right.$, dissolved $\mathrm{Mn}$, dissolved $\mathrm{Fe}$ and $\mathrm{SO}_{4}^{2-}$ ), and 19 for isotopic analysis. The sampling depths for isotopic analysis were selected based on chlorinated ethenes concentration. Two types of data notation have been used in this study; for instance, the label S- 6 refers to an average value for the whole multilevel well whereas S6-11.5 refers to the value from S-6 sampled at a depth of $11.5 \mathrm{~m}$ BGS.

Samples from the barrels found in the manufacturing building (collected in October 2002) and underground tank (collected in October 2002, June 2003, and September 2004) were also analysed. In July 2005 all of the abandoned barrels and contaminated soil from the underground tank and disposal lagoon areas were removed and transported to a disposal site. During excavation under the former disposal lagoon a water sample with a strong odour was collected from a fracture located above the water table and intercepted at $5.8 \mathrm{~m} \mathrm{BGS}$. The sample was considered to be representative of the liquid from the disposal lagoon. Further details about the multilevel monitoring devices and sample collection procedures are available in the SI (Section 1.1).

\subsection{Analytical methods}

Major anion contents were determined by High Performance Liquid Chromatography (HPLC), and major cations and trace element concentrations were determined by Inductively Coupled Plasma-Optical
Emission Spectrometry (ICP-OES) and Inductively Coupled PlasmaMass Spectrometry (ICP-MS), respectively. Alkalinity (as $\mathrm{HCO}_{3}^{-}$) was analysed from unfiltered samples by automatic titration, and DOC analysis was performed using a TOC-5000 total organic carbon analyzer (Shimadzu Scientific Instruments, Columbia, MD, USA) following the USEPA Method 9060 A. Concentrations of chlorinated ethenes in groundwater samples were determined by headspace (HS) analysis using a FOCUS Gas Chromatograph coupled with a DSQ II Mass Spectrometer (GC-MS) (Thermo Fisher Scientific, Waltham, MA, USA).

Isotope data are reported using the delta notation, $\delta\left({ }^{13} \mathrm{C}\right.$ or $\left.{ }^{37} \mathrm{Cl}\right)=$ $\left(R_{s} / R_{\text {std }}\right)-1$ (Eq. 1), where $R_{s}$ and $R_{\text {std }}$ are the ${ }^{13} \mathrm{C} /{ }^{12} \mathrm{C}$ and ${ }^{37} \mathrm{Cl} /{ }^{35} \mathrm{Cl}$ ratios of the sample and international standards; i.e., Vienna PeeDee Belemnite (VPDB) and Standard Mean Ocean Chloride (SMOC), respectively. The concentration-weighted average $\delta^{13} \mathrm{C}$ of PCE, TCE and CDCE was estimated according to $\delta^{13} C_{\text {sum }}=\Sigma\left(c_{i} \cdot \delta^{13} C_{i}\right) / c_{\text {sum }}$ (Eq. 2), where $c_{i}$ and $\delta^{13} C_{i}$ are the molar concentration and the isotope composition of each compound respectively, and $c_{\text {sum }}$ is the total molar concentration of all contributors. In this paper the terms enrichment and depletion consistently refer to enrichment or depletion of the heavy isotope $\left({ }^{13} \mathrm{C}\right.$ and $\left.{ }^{37} \mathrm{Cl}\right)$. The isotopic fractionation $(\varepsilon)$ is used to quantify the degree of enrichment (negative values) or depletion (positive values) during compound transformation or phase transfer processes. The $\varepsilon$ values can be calculated using a modified form of the Rayleigh distillation equation, $\ln \left(\mathrm{R} / \mathrm{R}_{0}\right)=\varepsilon \cdot \ln f$ (Eq. 3), where $\mathrm{R}$ and 
$\mathrm{R}_{0}$ are the current and initial isotope ratios respectively and $f$ the compound remaining fraction $\left(\mathrm{C} / \mathrm{C}_{0}\right)$.

Carbon isotope ratios of chlorinated ethenes were determined by CSIA using headspace solid-phase microextraction (HE-SPME) and a gas chromatograph coupled with an isotope ratio mass spectrometer through a combustion interface (GC-C-IRMS). The method and equipment used are described in detail in Palau et al. (2007). The precisions obtained from multi-component aqueous standards were $\pm 0.3 \%$, $\pm 0.2 \%$, and $\pm 0.4 \%$ o for PCE, TCE, and CDCE, respectively. Chlorine isotope ratios of TCE in groundwater samples were determined by CSIA using HE-SPME and a gas chromatograph coupled with a continuous flow isotope ratio mass spectrometer (GC-CF-IRMS). The method and equipment used are described thoroughly in Shouakar-Stash et al. (2006). The precision was $\pm 0.06 \%$ ofor TCE.

\section{Results and discussion}

Results include an evaluation of the isotopic composition of all potential sources, the redox conditions in the aquifer, the concentration and isotopic pattern of chlorinated ethenes, and the identification of biodegradation (Fig. 2) and mixing processes using a reactive transport model. Two transects along groundwater flow lines were used to characterize the groundwater contaminant plumes (see Fig. 1). Transect A (57 $\mathrm{m}$ long) started near the former disposal lagoon and included S-1 and S-4 wells. Transect B (80 m long) started near the underground tank and included S-3, S-6, and S-10 wells.

\subsection{Potential sources of chlorinated ethenes}

The study site was affected by several chlorinated VOC including the primary contaminants TCE, the most abundant chlorinated ethene, and PCE. Water samples collected from the underground tank, the main suspected source, had TCE concentrations up to $108.5 \mathrm{mg} / \mathrm{L}$ and $27.7 \mathrm{mg} / \mathrm{L}$ of PCE (Table 1). TCE values of $27.0 \mathrm{mg} / \mathrm{L}$ and PCE $1.6 \mathrm{mg} / \mathrm{L}$ were obtained in a sample from the fracture located under the former disposal lagoon. Finally, high concentrations were found in abandoned barrels at the site, with values of up to 1330 and $15.6 \mathrm{mg} / \mathrm{L}$ for PCE and TCE respectively. Almost no CDCE was detected in all the potential sources, with concentrations of $<0.01 \mathrm{mg} / \mathrm{L}$ in the barrels and the tank, and $<0.001 \mathrm{mg} / \mathrm{L}$ in fracture samples. These low values together with constant carbon isotope ratios of TCE and PCE in the tank $(-16.3 \pm 0.6 \%$ ond $-18.9 \pm 0.4 \%$ orespectively) throughout the sampling period indicate insignificant biodegradation at the potential sources (Table 1). Furthermore, the wide range of $\delta^{13} \mathrm{C}$ values for TCE and PCE in the potential VOC sources (Table 1), suggests that this site is suitable for using the carbon isotope fingerprint approach to determine the origin of the solvents in the groundwater.

Values of $\delta^{13} \mathrm{C}_{\mathrm{TCE}}$ for the sources show large differences between the barrel $(-40.5 \%$ o, the fracture sample $(-23.9 \%$ o $)$ and the tank $(-16.3 \pm 0.6 \%, \mathrm{n}=3)$ (Table 1$)$. These values are beyond the range of common published values for pure phase TCE, i.e. -31.6 to $-27.4 \%$ (Shouakar-Stash et al., 2003). The barrel B-29 value could not be explained by continuous vaporization, as a shift of only $-1.6 \%$ in $\delta^{13} \mathrm{C}$ can occur after $99 \%$ of evaporation ( $\varepsilon$ between of $+0.24 \%$ and $+0.35 \%$ ) (Huang et al., 1999; Jeannottat and Hunkeler, 2012; Poulson and Drever, 1999). However, the $\delta^{13} \mathrm{C}_{\mathrm{TCE}}$ of $-40.5 \%$ c could be explained by a much depleted ${ }^{13} \mathrm{C}$ precursor being used for production of TCE. Ertl et al.(1998) found a value as low as $-48.0 \pm 0.1 \%$ associated with TCE produced from acetylene. The ${ }^{13} \mathrm{C}$ enrichment of TCE for the tank and fracture samples compared to the reported manufacture's range could be due to isotope fractionating reactions during the synthesis of chlorinated pesticides and compounds for the textile industry by the plant at the site. The $\delta^{37} \mathrm{Cl}_{\mathrm{TCE}}$ values of both the tank and fracture samples, +0.53 and $+0.66 \%$ respectively (Table 1 ), fall within the range ( -3.19 to $+3.90 \%$ ) indicated by Shouakar-Stash et al. (2003) for pure TCE. The narrow chlorine isotope range of potential sources limits the use of $\delta^{37} \mathrm{Cl}_{\mathrm{TCE}}$ data for fingerprinting purposes.

For $\delta^{13} C_{\text {PCE }}$, differences of up to $12 \%$ o between barrels ( -20.3 to $-32.4 \%$ ) were measured, and the underground tank and the fracture sample were $-18.9 \pm 0.4 \%$ o $(n=3)$ and $-20.3 \pm 0.3 \%$ o respectively (Table 1). The $\delta^{13} \mathrm{C}_{\mathrm{PCE}}$ values of -26.1 and $-32.4 \%$ for the barrels B-29 and B-4, respectively, are within the range of PCE reported for different manufacturers (Jendrzejewski et al., 2001); whereas barrel B-20, fracture, and tank samples (ranging between -20.3 and $-18.5 \%$ ) were enriched. An inverse carbon isotopic effect associated with continuous vaporization of pure TCE and dichloromethane $\left(\varepsilon_{C}<+0.7 \%\right.$ o $)$ was determined in different experimental studies (Huang et al., 1999; Jeannottat and Hunkeler, 2012) and the same isotopic effect is thus expected for PCE. The inverse isotopic effect results in more negative isotope values in the remaining compound; therefore, vaporization cannot explain the source enriched $\delta^{13} \mathrm{C}_{\mathrm{PCE}}$ values. Similarly to TCE, the use of PCE in manufacturing processes could explain its enriched isotopic compositions found for the potential sources in this study.

\subsection{Redox conditions}

It is well known that the biodegradation of highly chlorinated ethenes in groundwater (Fig. 2) mostly occurs in anaerobic environments (Ferguson and Pietari, 2000; Wiedemeier, 1999). Redox conditions
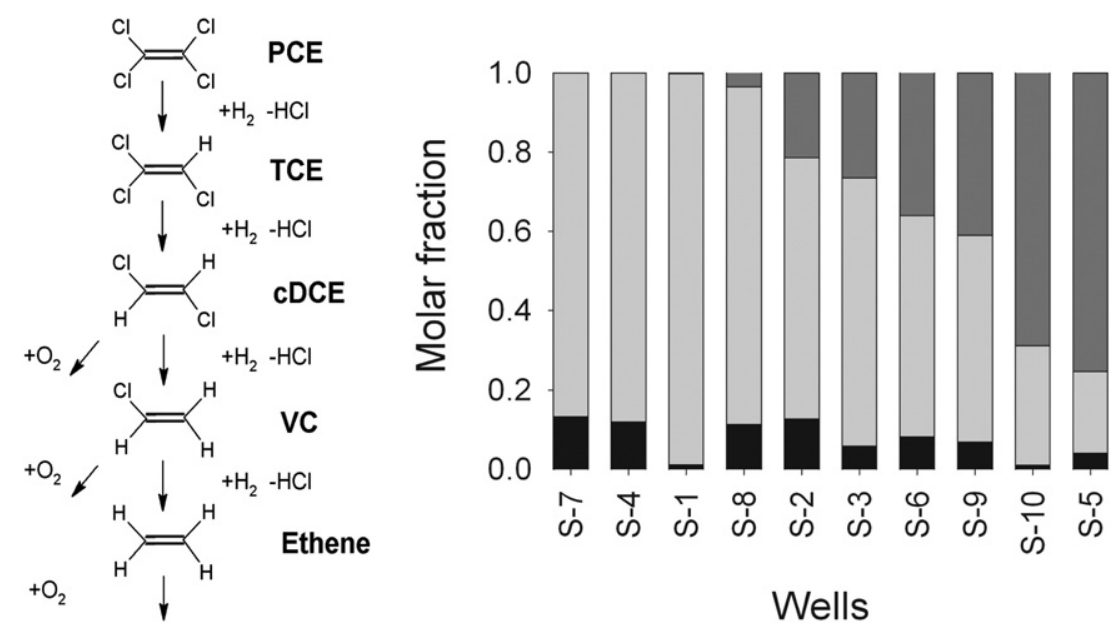

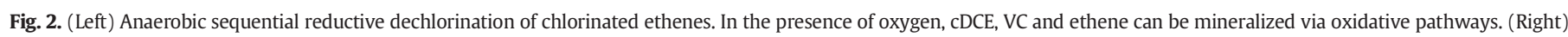
Average mole fractions of chlorinated ethenes in different parts of the aquifer: PCE (black), TCE (grey) and cDCE (dark grey). 
Table 1

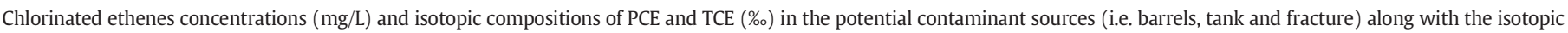
reported ranges from different manufacturers.

\begin{tabular}{|c|c|c|c|c|c|c|c|c|}
\hline \multirow[t]{2}{*}{ Compound } & \multicolumn{3}{|l|}{ Barrels } & \multicolumn{3}{|l|}{ Tank } & \multirow{2}{*}{$\frac{\text { Fracture }}{\text { Jul-05 }}$} & \multirow[t]{2}{*}{ Manufacturers' range $\mathrm{a}^{\mathrm{a}}$} \\
\hline & B-29 & B-4 & B-20 & Oct-02 & Jun-03 & Sep-04 & & \\
\hline PCE & 575.1 & 1333.0 & 5.2 & 27.7 & 1.2 & 2.8 & 1.6 & - \\
\hline TCE & 12.4 & 15.6 & $<0.01$ & 108.5 & 7.1 & 12.2 & 27.0 & - \\
\hline cDCE & $<0.01$ & $<0.01$ & $<0.01$ & $<0.01$ & $<0.01$ & $<0.01$ & $<0.001$ & - \\
\hline$\delta^{13} C_{\text {PCE } / \mathrm{NPDB}}$ & $-26.1 \pm 0.5$ & $-32.4 \pm 0.5$ & $-20.3 \pm 0.9$ & $-18.5 \pm 0.5$ & $-18.9 \pm 0.5$ & $-19.3 \pm 0.4$ & $-20.3 \pm 0.3$ & -23.2 to -37.2 \\
\hline$\delta^{13} \mathrm{C}_{\mathrm{TCE} / \mathrm{VPDB}}$ & $-40.5 \pm 0.5$ & - & - & $-16.6 \pm 0.5$ & $-15.6 \pm 0.5$ & $-16.8 \pm 0.3$ & $-23.9 \pm 0.2$ & -27.4 to -31.6 \\
\hline$\delta^{37} \mathrm{Cl}_{\mathrm{TCE} / \mathrm{SMOC}}$ & - & - & - & - & - & $+0.66 \pm 0.06$ & $+0.53 \pm 0.06$ & -3.19 to +3.90 \\
\hline
\end{tabular}

a Sources are indicated in Section 3.1.

were described using $\mathrm{DO}, \mathrm{NO}_{3}^{-}, \mathrm{NO}_{2}^{-}$, dissolved $\mathrm{Mn}$, dissolved Fe and $\mathrm{SO}_{4}^{2-}$ concentrations in the aquifer. The hydrochemical data showed redox gradients from aerobic to sulphate-reducing conditions.

In transect A manganese-reducing conditions were determined near the source area (S-1) overlapping with iron-reduction in the lower part (dissolved Mn 2.0-2.2 mg/L and dissolved Fe 0.04-1.61 mg/L). The observed reducing conditions close to the source agree with the high DOC concentration found in this area $(95 \mathrm{mg} / \mathrm{L})$. Well S-4 showed strong reducing conditions (sulphate-reducing) only in the lower part (S4-16), with a sulphate concentration as low as $239 \mathrm{mg} / \mathrm{L}$ compared to the average site value of $1314 \mathrm{mg} / \mathrm{L}$, whereas anaerobic conditions were assigned at the upper part ( $\mathrm{DO}<0.84 \mathrm{mg} / \mathrm{L}$ and $\mathrm{NO}_{3}^{-} 188.5 \mathrm{mg} / \mathrm{L}$ ).

In transect $\mathrm{B}$, iron/manganese-reducing conditions were determined in the underground tank area (S-3) $\left(\mathrm{NO}_{3}^{-}<1.5 \mathrm{mg} / \mathrm{L}\right.$, dissolved $\mathrm{Mn}$ $0.5-1.4 \mathrm{mg} / \mathrm{L}$ and dissolved Fe $0.5-1.2 \mathrm{mg} / \mathrm{L})$. Decrease in sulphate concentration from $1157 \mathrm{mg} / \mathrm{L}$ at S3-13.6 to $929 \mathrm{mg} / \mathrm{L}$ at S3-17.6 might indicate the use of sulphate as terminal electron acceptor. A trend towards oxic conditions was observed as groundwater moves downstream, reaching aerobic conditions in S-10, where nitrate and dissolved oxygen were present at concentrations of up to 96.4 and $3.0 \mathrm{mg} / \mathrm{L}$, respectively. The redox gradient concurred with the DOC, with concentrations ranging from 78 to $114 \mathrm{mg} / \mathrm{L}$ in $\mathrm{S}-3,10 \mathrm{mg} / \mathrm{L}$ in S-6 and $<6.5 \mathrm{mg} / \mathrm{L}$ in S-10.

In both transects reducing conditions suitable for chlorinated ethenes biodegradation via reductive dechlorination were mainly present near the potential sources (Fig. 3).

\subsection{Chlorinated ethenes concentration and isotope data}

In order to demonstrate the presence of multiple plumes and to relate the plumes to their possible sources regardless of the biodegradation processes, concentration and $\delta^{13} \mathrm{C}$ values for PCE, TCE and, the concentration-weighted average $\delta^{13} \mathrm{C}$ of PCE, TCE and CDCE $\left(\delta^{13} \mathrm{C}_{\text {sum }}\right.$, see Eq. 2) were evaluated. Assuming that the carbon pool is conservative during the reaction and transport (Bloom et al., 2000; Hunkeler et al., 2004), the $\delta^{13} C_{\text {sum }}$ should be similar to the source throughout the plume, whereas significant deviations may indicate a mixture with other sources or the occurrence of different degradation pathways. Vinyl chloride was not included in the isotopic mass balance due to its low concentration $(<5 \mu \mathrm{g} / \mathrm{L})$, suggesting that cDCE was not significantly degraded by reductive dechlorination (Fig. 2).

The chlorinated ethenes concentration data from multilevel wells revealed several hot spots (Fig. 1) and significant variations with depth and along groundwater flow lines (Fig. 3). The highest TCE and PCE concentrations were detected near the potential sources (S-3, S-1, and S-8) and reached values of up to 50 and $6 \mathrm{mg} / \mathrm{L}$ for TCE and PCE respectively. Chlorinated ethenes concentration decreased significantly downgradient along groundwater flow lines except at the S-4 well, which showed TCE and PCE concentrations higher than in S-1 (transect A). However, high TCE and CDCE concentrations were still observed in S-6 (transect B) (Fig. 3). The increase of cDCE molar fraction downstream along transect $B$ indicated a contribution of biodegradation to the attenuation of TCE along this plume (Fig. 2).
Concerning the isotopic data, the $\delta{ }^{13} \mathrm{C}$ values from the multilevel wells ranged from -23.1 to $-8.2 \%$ o for TCE and from -19.7 to $-16.2 \%$ for PCE, and $\delta^{37} \mathrm{Cl}$ values of TCE ranged from -0.07 to $+2.64 \%$ o (Table 2 ). This variability could be related to differences in the isotopic composition of the sources and/or the effects of biodegradation. The narrow range of $\delta^{13} \mathrm{C}_{\mathrm{PCE}}$ compared with the range of TCE could be associated with a restricted carbon isotopic range for the PCE sources at the study site. Furthermore, the smaller carbon isotopic fractionation for the microbial degradation of PCE compared to TCE should be considered (Bloom et al., 2000; Cichocka et al., 2007, 2008). The $\delta^{37} \mathrm{Cl}_{\mathrm{TCE}}$ in groundwater showed values higher than those of the potential sources (approximately $+0.6 \%$, Table 1 ), suggesting that the chlorine isotopic composition of TCE reflects the effect of biodegradation in the aquifer.

The $\delta^{13} \mathrm{C}$ of TCE near the plant source (approximately $-23 \%$ in S-8, Table 2 ) is much higher than the value of the barrel ( $-40.5 \%$ ) (Fig. 1). In addition, the $\delta^{13} \mathrm{C}_{\mathrm{PCE}}$ value of approximately $-18.5 \%$ in S-8 (Table 2 ) was also higher than the range obtained from the barrels, from -20.3 to $-32.4 \%$. Due to the differences of $\delta^{13} \mathrm{C}$ of TCE and PCE between the barrels and $\mathrm{S}-8$ it is not possible to confirm that the abandoned barrels were part of the TCE and PCE sources located under the plant.

The $\delta^{13} C_{\text {sum }}$ for multilevel wells, except S-2 and those in transect B, exhibited similar values ranging between -22.9 and $-19.4 \%$ (Fig. 1). These values are close to the disposal lagoon $(-23.7 \%$ ), whereas values for multilevel wells in transect B (S-3, S-6, S-10) and S-2 range from -17.6 to $-11.2 \%$ and are consistent with the underground tank $(-17.2 \%$, Sept-04). The difference in isotopic composition between the different wells allowed the use of isotopes and isotope balances to differentiate two chlorinated ethenes plumes.

\subsubsection{Transect $A$}

In transect $A, T C E$ maximum concentration increased downstream, from 13.6 to $18.1 \mathrm{mg} / \mathrm{L}$ for S-1 and S-4, respectively (Fig. 3). The $\delta^{13} \mathrm{C}_{\mathrm{TCE}}$ and $\delta^{37} \mathrm{Cl}_{\mathrm{TCE}}$ values of approximately -22 and $+1 \%$, respectively, were similar to the TCE leaching from contaminated soil under the former disposal lagoon (Table 1). PCE had a similar distribution as TCE but with much lower concentrations of up to $0.2 \mathrm{mg} / \mathrm{L}$ in S-1 and $2.1 \mathrm{mg} / \mathrm{L}$ in the middle part of S-4 (Fig. 3). The $\delta^{13} \mathrm{C}_{\mathrm{PCE}}$ values of -18.5 to $-19.7 \%$ in S-1 and S-4 respectively were consistent with the PCE leaching from contaminated soil at the disposal lagoon area $(-20.3 \%$ o). Therefore, the small isotopic enrichment observed in these wells indicated that TCE and PCE were not affected by significant biodegradation despite of the reducing conditions observed in this transect. This conclusion agrees with the low concentration of CDCE $(<30 \mu \mathrm{g} / \mathrm{L})$ measured in this part of the aquifer (Fig. 3). In summary, the isotope data shows that the former disposal lagoon was the source of the chlorinated ethenes in the area of transect $A$.

\subsubsection{Transect $B$}

In transect B, TCE concentration decreased from 37.8 to $0.3 \mathrm{mg} / \mathrm{L}$ for S-3 $(n=5)$ and S-10 $(n=12)$ respectively, whereas high cDCE concentrations (up to $12.6 \mathrm{mg} / \mathrm{L}$ for S3-13.6) were measured. PCE concentration was much lower than TCE, with a molar fraction of 0.06 near 

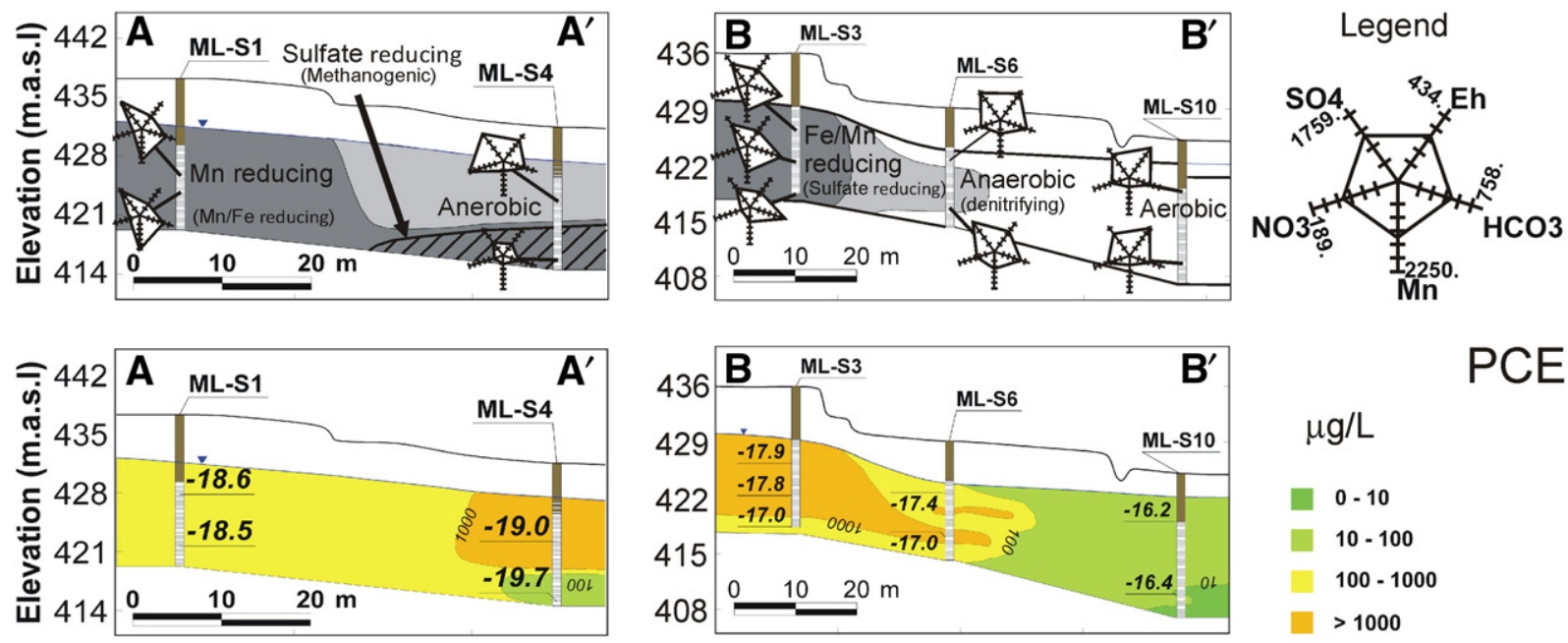

PCE
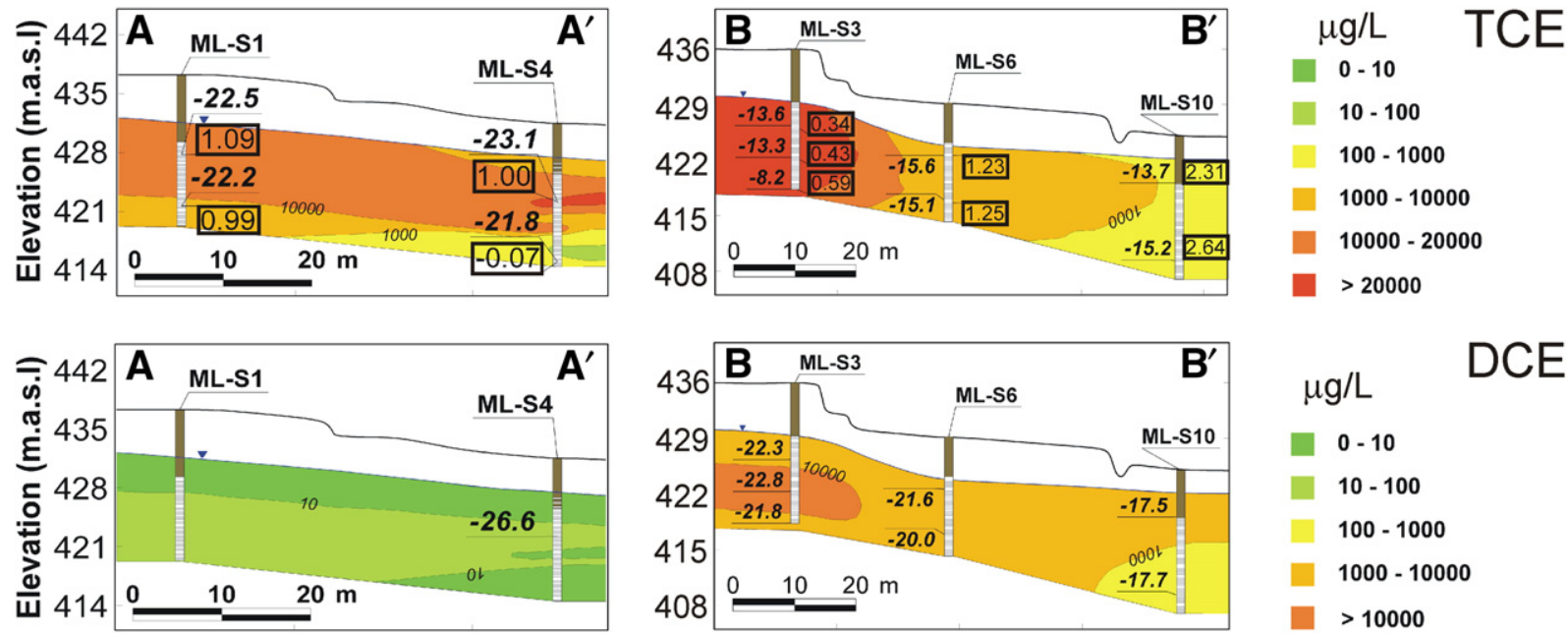

$\mu \mathrm{g} / \mathrm{L}$

$\mu g / L$

$0-10$

$10-100$

$100-1000$

$>1000$

$>20000$

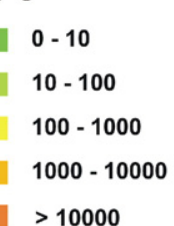

DCE

Fig. 3. (From top to bottom) Identified redox conditions along transects $\mathrm{A}-\mathrm{A}^{\prime}$ and $\mathrm{B}-\mathrm{B}^{\prime}$ (see Fig. $1 \mathrm{~A}$ ). Several redox parameters are represented with radial diagrams: $\mathrm{SO}_{4}^{2-}$, $\mathrm{NO}_{3}^{-}$and $\mathrm{HCO}_{3}^{-}$ concentrations are indicated in $\mathrm{mg} / \mathrm{L}, \mathrm{Mn}$ (II) in $\mu \mathrm{g} / \mathrm{L}$ and $\mathrm{Eh}$ in $\mathrm{mV}$ (values available in the SI, Tables S5 and S6, Section 3). Diagram scales range from zero to the maximum value measured for each parameter in each transect. PCE, TCE and CDCE concentrations (Table S4 in the SI, Section 3) and $\delta^{13} \mathrm{C}(\%)$ values along transects A- $\mathrm{A}^{\prime}$ and B-B'. For TCE, $\delta^{13} \mathrm{C}\left(\right.$ bold italics) and $\delta^{37} \mathrm{Cl}$ (standard in boxes) (\%) are indicated.

Table 2

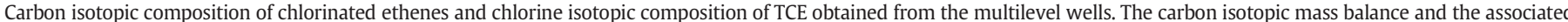
concentration-weighted average $\delta^{13} \mathrm{C}_{\text {sum }}$ in each well are also indicated (the uncertainties were estimated using the law of propagation of uncertainty).

\begin{tabular}{|c|c|c|c|c|c|c|c|c|c|c|c|}
\hline \multirow[t]{2}{*}{ Location } & \multirow[t]{2}{*}{ Multilevel well } & \multirow{2}{*}{$\frac{\text { Sampling depth }}{(\mathrm{m} \mathrm{BGS})}$} & \multicolumn{3}{|l|}{$\mu \mathrm{M}$} & \multicolumn{3}{|l|}{$\delta^{13} \mathrm{C}_{\mathrm{VPDB}}(\%)$} & \multirow{2}{*}{$\frac{\text { Isotope balance }}{\delta^{13} \mathrm{C}_{\text {sum }}(\%)}$} & \multirow{2}{*}{$\frac{\text { Weighted-average }}{\delta^{13} C_{\text {sum }}(\%)}$} & \multirow{2}{*}{$\frac{\delta^{37} \mathrm{Cl}_{\mathrm{SMOC}}(\% \circ)( \pm 0.06)}{\mathrm{TCE}}$} \\
\hline & & & PCE & $\mathrm{TCE}$ & $\overline{c D C E}$ & PCE & $\mathrm{TCE}$ & $\mathrm{cDCE}$ & & & \\
\hline \multirow[t]{4}{*}{ Transect A } & $\mathrm{S} 1$ & 9.53 & 1.0 & 103.5 & & $-18.6 \pm 0.3$ & $-22.5 \pm 0.2$ & - & $-22.5 \pm 0.2$ & $-22.3 \pm 0.2$ & +1.09 \\
\hline & $\mathrm{S} 1$ & 15.61 & 0.8 & 74.6 & 0.3 & $-18.5 \pm 0.3$ & $-22.2 \pm 0.3$ & - & $-22.1 \pm 0.3$ & & +0.99 \\
\hline & S4 & 9.31 & 6.6 & 137.8 & 0.2 & $-19.0 \pm 0.3$ & $-23.1 \pm 0.4$ & $-26.6 \pm 0.5$ & $-22.9 \pm 0.4$ & $-22.9 \pm 0.4$ & +1.00 \\
\hline & S4 & 16.41 & 0.5 & 4.8 & - & $-19.7 \pm 0.3$ & $-21.8 \pm 0.4$ & - & $-21.6 \pm 0.4$ & & -0.07 \\
\hline \multirow[t]{7}{*}{ Transect B } & S3 & 9.60 & 31.4 & 253.5 & 87.7 & $-17.9 \pm 0.3$ & $-13.6 \pm 0.2$ & $-22.3 \pm 0.4$ & $-16.0 \pm 0.3$ & $-15.3 \pm 0.2$ & +0.34 \\
\hline & S3 & 13.60 & 38.6 & 380.6 & 130.0 & $-17.8 \pm 0.3$ & $-13.3 \pm 0.2$ & $-22.8 \pm 0.4$ & $-15.9 \pm 0.3$ & & +0.43 \\
\hline & S3 & 17.60 & 5.1 & 157.6 & 83.6 & $-17.0 \pm 0.3$ & $-8.2 \pm 0.2$ & $-21.8 \pm 0.4$ & $-13.0 \pm 0.5$ & & +0.59 \\
\hline & S6 & 6.60 & 7.7 & 58.6 & 31.1 & $-17.4 \pm 0.3$ & $-15.6 \pm 0.2$ & $-21.6 \pm 0.5$ & $-17.7 \pm 0.3$ & $-17.6 \pm 0.2$ & +1.23 \\
\hline & S6 & 12.60 & 6.8 & 48.0 & 51.6 & $-17.0 \pm 0.3$ & $-15.1 \pm 0.6$ & $-20.0 \pm 0.5$ & $-17.6 \pm 0.4$ & & +1.25 \\
\hline & S10 & 5.84 & 0.3 & 6.9 & 16.0 & $-16.2 \pm 0.3$ & $-13.7 \pm 0.2$ & $-17.5 \pm 0.4$ & $-16.4 \pm 0.3$ & $-16.4 \pm 0.3$ & +2.31 \\
\hline & $\mathrm{S} 10$ & 15.84 & 0.1 & 2.0 & 3.1 & $-16.4 \pm 0.3$ & $-15.2 \pm 0.4$ & $-17.7 \pm 0.4$ & $-16.7 \pm 0.3$ & & +2.64 \\
\hline \multirow[t]{8}{*}{ Other areas } & S5 & 11.27 & 0.1 & 0.4 & 3.0 & $-19.0 \pm 0.3$ & $-18.6 \pm 0.4$ & $-20.8 \pm 0.5$ & $-20.4 \pm 0.4$ & - & +1.60 \\
\hline & S7 & 7.79 & 1.7 & 7.6 & n.d. ${ }^{a}$ & $-18.9 \pm 0.7$ & $-19.6 \pm 0.7$ & - & $-19.5 \pm 0.6$ & $-19.4 \pm 0.5$ & +0.33 \\
\hline & S7 & 14.79 & 0.3 & 1.9 & n.d. ${ }^{a}$ & $-19.1 \pm 0.6$ & $-19.2 \pm 0.6$ & - & $-19.2 \pm 0.5$ & & +1.12 \\
\hline & S8 & 9.67 & 34.6 & 93.6 & 1.7 & $-18.4 \pm 0.5$ & $-23.1 \pm 0.5$ & - & $-21.5 \pm 0.4$ & $-21.9 \pm 0.4$ & +0.30 \\
\hline & S8 & 16.67 & 2.5 & 76.5 & 1.1 & $-18.6 \pm 0.6$ & $-22.8 \pm 0.5$ & - & $-22.4 \pm 0.5$ & & +0.45 \\
\hline & $\mathrm{S} 2$ & 13.60 & 0.1 & 0.4 & 0.1 & - & $-14.5 \pm 0.6$ & - & $-11.2 \pm 0.6$ & - & +1.04 \\
\hline & S9 & 6.74 & 1.7 & 21.8 & 6.9 & $-17.3 \pm 0.5$ & $-22.2 \pm 0.4$ & $-20.7 \pm 0.4$ & $-21.6 \pm 0.3$ & $-21.5 \pm 0.3$ & +0.91 \\
\hline & S9 & 16.74 & 0.2 & 1.5 & 0.8 & $-17.1 \pm 0.3$ & $-21.2 \pm 0.2$ & $-19.4 \pm 0.4$ & $-20.3 \pm 0.2$ & & +1.26 \\
\hline
\end{tabular}

\footnotetext{
a Not detected.
} 
the source (Fig. 2), and also decreased along the plume, from 4.4 to $0.02 \mathrm{mg} / \mathrm{L}$ for $\mathrm{S}-3(\mathrm{n}=5)$ and $\mathrm{S}-10(\mathrm{n}=12)$ respectively.

With regard to carbon isotopic composition, a significant shift in $\delta^{13} \mathrm{C}_{\mathrm{TCE}}$ from -15.6 to $-8.2 \%$ and $\delta{ }^{13} \mathrm{C}_{\mathrm{PCE}}$ from -17.9 to $-16.2 \%$ 。 was observed in transect B (Fig. 3). The isotope values for TCE and PCE in the high concentration spot at S-3 were close to those of the underground tank, confirming that the tank was the source of the chlorinated ethenes in the area of transect B. A large shift towards enriched $\delta^{13} \mathrm{C}$ values with depth was observed for TCE $(-13.6$ to $-8.2 \%$ ) at S-3, which points to the occurrence of TCE biodegradation. These isotopic data were consistent with high cDCE concentrations (up to $12 \mathrm{mg} / \mathrm{L}$ ) and the stronger reducing conditions observed in this part of the aquifer.

Downstream from S-3 (S-6 and S-10), the decrease in TCE concentration along the groundwater flow direction was not associated with a trend to more enriched $\delta^{13} C_{\text {TCE. }}$. The values in S-6 and S-10 remained depleted in ${ }^{13} \mathrm{C}$ compared to $\mathrm{S}-3$ and the underground tank (Fig. 3 ). However, the fact that CDCE molar fraction increased along the flow path (Fig. 2), $\delta^{13} C_{C D C E}$ shifted toward more enriched values (from $-22.8 \%$ o to $-17.5 \%$ ), and that $\delta^{37} \mathrm{Cl}_{\mathrm{TCE}}$ shifted as well to higher values (from $+0.34 \%$ o to $+2.64 \%$ ) suggests the occurrence of TCE degradation along this transect (Fig. 3). In contrast to the $\delta^{13} \mathrm{C}$ results for TCE, the $\delta^{13} \mathrm{C}_{\mathrm{PCE}}$ exhibited a trend towards more enriched values, concomitant with a decrease in concentration along the flow line, indicating PCE biodegradation. This possibility was further supported by the lower PCE molar fraction in S-10 in comparison with the upstream wells (Fig. 2). The fact that $\delta^{13} \mathrm{C}_{\mathrm{CDCE}}$ values never reached higher values than TCE or PCE agreed with the low VC concentration $(<5 \mu \mathrm{g} / \mathrm{L})$ and confirmed that $C D C E$ was not further degraded. This was valuable information for site management as it indicated that chlorinated ethenes reductive dechlorination was not complete and that $\mathrm{CDCE}$ is likely to accumulate (Fig. 2). Because of the site complexity, it is not possible to determine where the potential biodegradation processes are taking place. The geochemical conditions (see Section 3.2) are not conducive to reductive dechlorination in the vicinity of S-6 and S-10; however, the presence of micro-redox zones with stronger reducing conditions is possible in such fractured bedrock aquifer (Christensen et al., 2000; Wiegert et al., 2012).

The isotopic composition of TCE $\left(\delta^{13} \mathrm{C}\right.$ and $\left.\delta^{37} \mathrm{Cl}\right)$ versus its remaining concentration is plotted in Fig. 4 for multilevel S-3, S-6, and S-10 (plume along transect $\mathrm{B}$ ). The $\delta^{37} \mathrm{Cl}_{\mathrm{TCE}}$ values showed a Rayleigh trend indicating TCE biodegradation. However, as biodegradation induces isotope fractionation towards more enriched isotope values for both carbon and chlorine (Hunkeler et al., 2009; Wiegert et al., 2013) and this behaviour is not found for carbon isotopes, it is suggested that another process exists. In fact the depleted $\delta^{13} \mathrm{C}_{\mathrm{TCE}}$ values measured downstream from the source (S-6 and S-10) point to a mixing with TCE from other sources or plumes, or to a contribution of TCE depleted in ${ }^{13} \mathrm{C}$ originating from biodegradation of PCE. Due to the low molar fraction of PCE in comparison to TCE (Fig. 2), variations of carbon and chlorine isotope values of TCE related to biodegradation of PCE are likely small or insignificant. The effect of PCE biodegradation on the isotopic signature of TCE along the plume is further discussed using the reactive transport model (see below and in SI, Fig. S3 in Section 2.2). However, significant masking of enriched $\delta^{13} \mathrm{C}_{\mathrm{TCE}}$ values due to biodegradation might be explained by mixing of different sources. The impact of source mixing on the isotopic signature of TCE depends on the concentration and isotopic composition in each source. This impact generally will be different for distinct compounds present in both sources but also for distinct elements in the same compound.

Diffusion induced carbon isotope fractionation in groundwater could also mask the ${ }^{13} \mathrm{C}$ enrichment associated with biodegradation (Van Breukelen and Rolle, 2012). But the effect of diffusion induced fractionation during transverse hydrodynamic dispersion might be difficult to observe in highly heterogeneous environments such as fractured aquifers, where advection and macro-dispersion dominate the contaminant transport (Thullner et al., 2012).

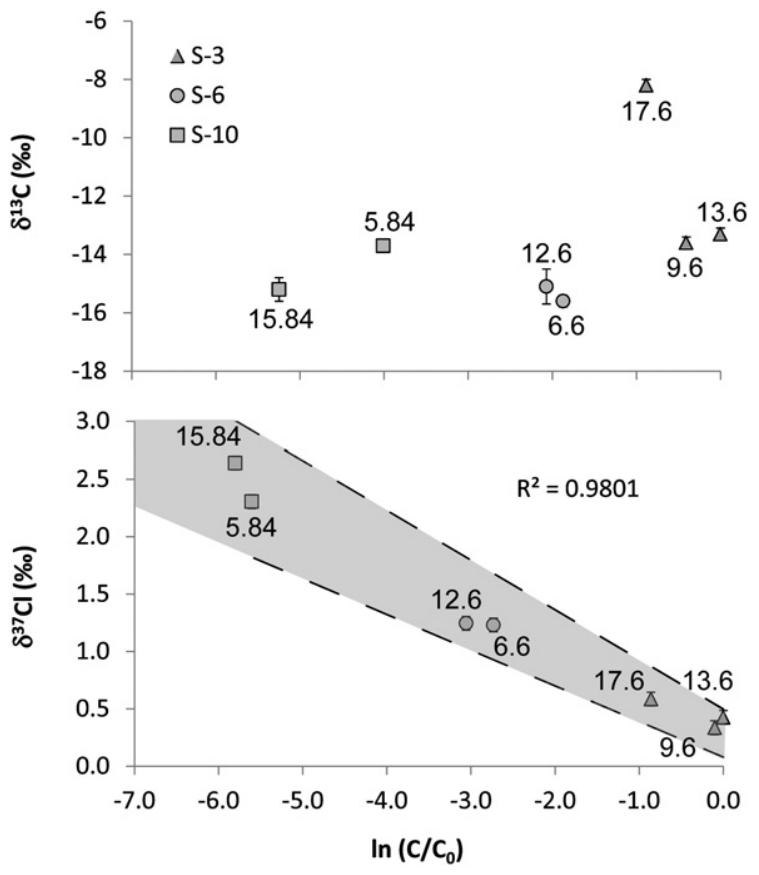

Fig. 4. $\delta^{13} \mathrm{C}_{\mathrm{TCE}}$ and $\delta^{37} \mathrm{Cl}_{\mathrm{TCE}}$ versus TCE remaining concentration along transect $\mathrm{B}-\mathrm{B}^{\prime}$. The initial concentration $\left(C_{0}\right)$ corresponds to the value of S3-13.6. Sampling depths are indicated next to the symbols and the shaded area represents $95 \%$ confidence of regression parameters.

The influence of mixing on the isotopic signature of TCE and PCE was further investigated using a reactive transport model (see Section 3.4).

\subsection{Reactive solute transport modelling}

A reactive solute transport model was used to examine the processes and sources involved in the transect B plume and to determine whether the observed isotope pattern (Fig. 4) resulted from the simultaneous effect of mixing and biodegradation. Different conceptual scenarios regarding both processes were investigated. A multi-component reactive transport model was set up in Comsol Multiphysics to simulate two-dimensional transport, degradation reactions, and consequently isotope fractionation. Concentration and isotopic data of TCE, PCE, and CDCE were simulated along the upper part of transect $B$. The average concentration and isotopic composition of the samples collected from the two upper screens in multilevel wells S-3, S-6 and S-10 were used as input data for the model. The variation of concentration and isotopic composition with depth were not included in the model since the main purpose was to investigate the processes occurring along the ground water flow direction. Details are provided in SI (Section 2).

The results obtained during calibration of transport parameters using the total chlorinated ethene concentration showed that attenuation due to dispersion and dilution is large along transect $\mathrm{B}$, and the chlorinated ethenes concentrations can be simulated well without any degradation processes (Fig. S2 in SI, Section 2.1). While the simple advective-dispersive model can match the concentration values, it is not consistent with isotopic data which showed that degradation was occurring. This means that isotopic data are crucial to document chlorinated ethenes dechlorination along the flow line. The isotopic fractionation has been implemented in the model according to Hunkeler et al. (2009), and the $\varepsilon$ values and degradation rates are calibrated using a range of values provided in the literature (Hunkeler et al., 2008) (Table S3 in SI, Section 2.2).

Four conceptual models were simulated based on the concentration and isotope data described in Section 3.3 (see details in SI, Section 2.3). For models 1 and 2 the only source was the underground tank: in model 1 reductive dechlorination to cDCE occurred along the flow line whereas 
in model 2 stepwise reductive dechlorination was simulated (to TCE between S-3 and S-6 and, to cDCE downstream). Moreover, simultaneous biodegradation and source mixing was investigated in models 3 and 4 . In model 3 the chlorinated ethenes plume from the tank source was mixed by dispersion with the transect A plume, while in model 4 the tank plume was mixed with TCE leaching from the unsaturated zone between S-3 and S- 6 .

Chlorinated ethenes concentrations were well described by all of the models (Fig. 5). Results for the carbon isotopic composition of TCE for models 1 and 2 show a slight increase of $\delta^{13} \mathrm{C}_{\mathrm{TCE}}$ along the flow line indicating that depleted $\delta^{13} C_{\text {TCE }}$ values (mainly at S-6) cannot solely be explained by PCE dechlorination. This is also true for model 2 where TCE is not degraded between S-3 and S-6. A better simulation was obtained after including mixing processes and model 4 reproduced the measured $\delta^{13} \mathrm{C}_{\mathrm{TCE}}$ values fairly well. These results lead to the conclusion that mixing with another source of TCE controlled the $\delta^{13} \mathrm{C}_{\mathrm{TCE}}$, supporting the interpretation of field data discussed in Section 3.3.2. In contrast, all of the proposed models clearly reproduced the observed trend to higher values of $\delta^{37} \mathrm{Cl}_{\mathrm{TCE}}$ and $\delta^{13} \mathrm{C}_{\mathrm{PCE}}$, with the exception of $\delta^{37} \mathrm{Cl}_{\mathrm{TCE}}$ in model 2, suggesting that these isotopic compositions were mainly controlled by biodegradation and that they were less affected by mixing than $\delta^{13} \mathrm{C}_{\mathrm{TCE}}$ (Fig. 5). In this case, the lower impact of mixing on $\delta^{37} \mathrm{Cl}_{\mathrm{TCE}}$ and $\delta^{13} \mathrm{C}_{\mathrm{PCE}}$ in comparison to $\delta^{13} \mathrm{C}_{\mathrm{TCE}}$ was due to the smaller isotopic differences between the sources (i.e. approximately $1 \%$ o for $\delta^{13} \mathrm{C}_{\mathrm{PCE}}$ and no difference for $\delta^{37} \mathrm{Cl}_{\mathrm{TCE}}$ between the tank and fracture, Table 1). The observed trend to higher $\delta^{13} C_{C D C E}$ values along the groundwater flow line was also simulated well by all of the models (Fig. 5); however, none of the considered models clearly reproduce the value measured in S-10. The enriched $\delta^{13} \mathrm{C}_{\mathrm{CDCE}}$ in $\mathrm{S}-10$ in comparison with the result of the model could be explained by the occurrence of other CDCE transformation pathways, such as abiotic degradation (Darlington et al., 2008).

Many other processes could improve the fit of the model simulations to observations, but were not considered in this study. The flow field was assumed to be at steady-state and the presence of high permeability fractures and vertical mixing was excluded. Reductive dechlorination was assumed to occur uniformly along the transect $\mathrm{B}$, but it is not clear where biodegradation was active, especially because heterogeneous reaction zones could be present in such fractured environments. Further refinement of the model would require more field data in order to balance the model complexity and the observation at the site. Nevertheless, despite the model simplifications, the results obtained indicate that the observed isotope pattern at the site can be explained by the simultaneous effect of source mixing and biodegradation processes. This kind of information is of interest for evaluation of contaminant natural attenuation in sites with multiple sources of contamination.

\section{Conclusions}

Despite of the difficulty in characterization of fractured bedrock sites contaminated with chlorinated ethenes, this study shows the potential of using multi-isotope data $\left({ }^{13} \mathrm{C} /{ }^{12} \mathrm{C}\right.$ and $\left.{ }^{37} \mathrm{Cl} /{ }^{35} \mathrm{Cl}\right)$ - in combination with delineation of contaminant distribution, redox conditions, and reactive transport modelling - for assessing contaminants' origin, fate, and transport at complex sites with multiple sources. The pollution of
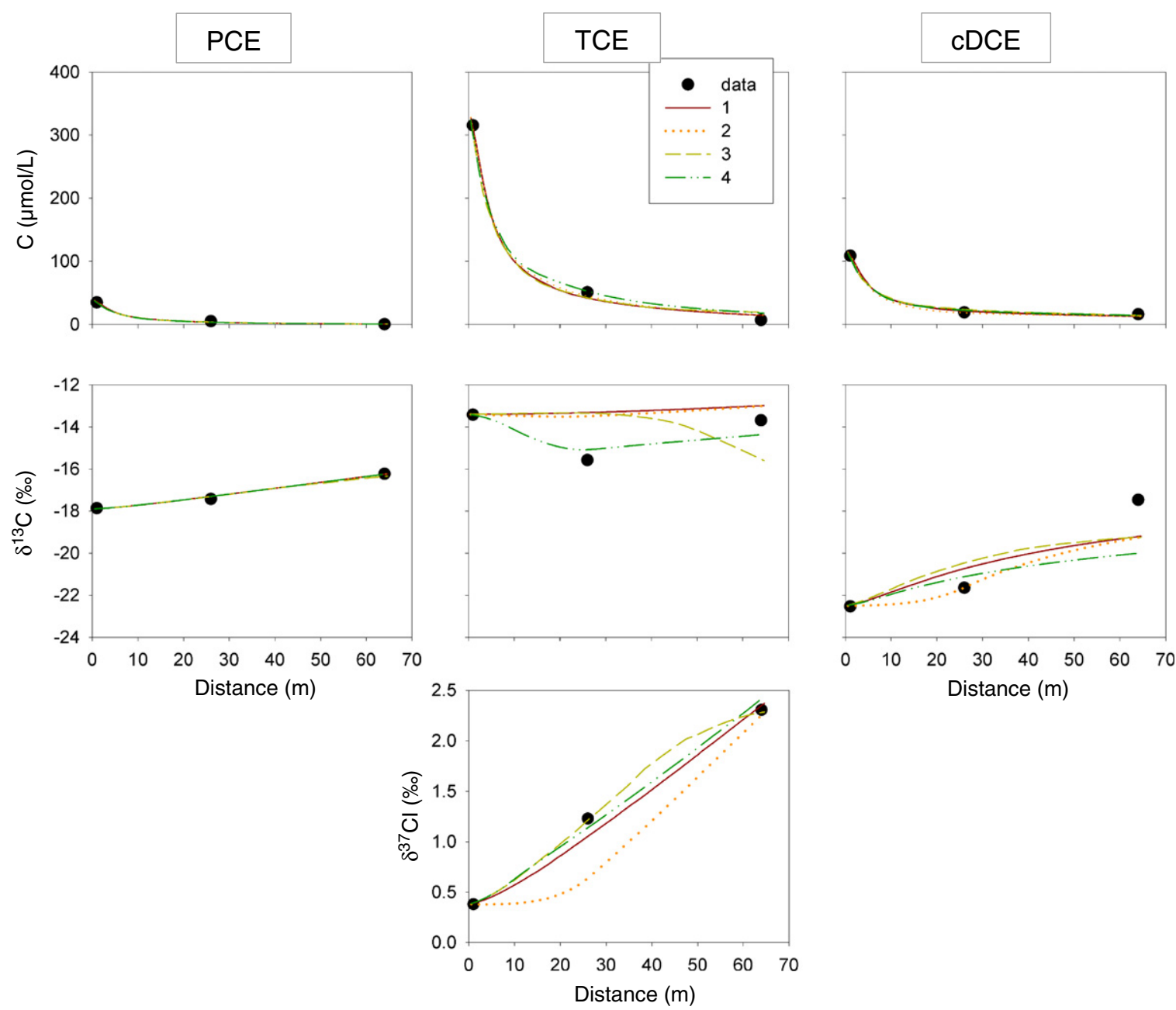

Fig. 5. Comparison of model simulations and field measurements for the four conceptual models of transect B. 
the studied site originated from a former chemical plant with three potential contaminant spot sources: barrels, disposal lagoon and underground tank

A wide range in $\delta^{13} \mathrm{C}_{\mathrm{TCE}}$ and $\delta^{13} \mathrm{C}_{\mathrm{PCE}}$ was found for the potential contaminant sources, with only two $\delta^{13} \mathrm{C}_{\mathrm{PCE}}$ barrel values (B-4 and $\mathrm{B}-29$ ) being within the reported manufacturers' ranges. The enriched ${ }^{13} \mathrm{C}$ isotopic signatures of TCE-PCE from the tank, in one fracture located below the disposal lagoon, and PCE in one barrel (B-2) compared to the manufacturers' ranges were likely to have resulted during their use as chemical intermediates by the plant at the site. However, the depleted $\delta^{13} \mathrm{C}$ value of the TCE found in one barrel was thought to be due to the carbon source used for its production.

The comparison of $\delta^{13} C_{\mathrm{TCE}}, \delta^{13} \mathrm{C}_{\mathrm{PCE}}$ and $\delta^{13} \mathrm{C}_{\text {sum }}$ between potential sources and multilevel wells allowed for the differentiation between two plumes in the fractured bedrock aquifer and the relation of these to the disposal lagoon (transect A) and the underground tank (transect B). No evidence of significant biodegradation of TCE and PCE was found in the isotopic signatures and daughter-product concentration data along transect $A$. In contrast, for transect $B$ a trend towards enriched $\delta^{13} \mathrm{C}$ values of PCE and CDCE concurrent with an increase of the CDCE molar fraction along the groundwater flow direction suggested PCE and TCE reductive dechlorination. However, the $\mathrm{C}$ and $\mathrm{Cl}$ isotope values for TCE revealed the concurrence of source mixing along the plume. A reactive transport model was used to simulate concentration and isotope data along transect $B$ and the results demonstrate that the observed isotope pattern for TCE can be explained by the simultaneous effect of source mixing and biodegradation. This information is of interest for the interpretation of CSIA data in complex field sites. Furthermore, the model allowed the conceptual evaluation of different scenarios including both processes.

Isotopic data was crucial to document chlorinated ethenes biodegradation and source mixing in this study, since measured contaminant concentrations along the groundwater flow direction can be simulated well by an advective-dispersive transport model without any degradation and source mixing process. The results of this study suggest that a combination of multi-isotope fingerprinting and numerical modelling is needed at contaminated sites where several contaminant sources and plumes are present.

\section{Conflict of interest statement}

The authors declare no competing financial interest.

\section{Acknowledgments}

This study was funded by the Spanish Government CICYT projects CGL2011-29975-C04-01 and by the Catalan Government project 2009 SGR 103. The authors would like to thank the "Agència Catalana de l'Aigua" (R. Corb) and the "Agència de Residus de Catalunya" (J.A. Domènech and J. Bartoll) for their support together with the "Centres Científics i Tecnològics" of the "Universitat de Barcelona" for the chemical and isotopic analyses. The contribution from the Technical University of Denmark was supported by the research project REMTEC, Innovative Remediation and Assessment Technologies for Contaminated Soil and Groundwater, Danish Council for Strategic Research and the Technical University of Denmark. We also thank two anonymous reviewers for constructive comments to improve the clarity of this article.

\section{Appendix A. Supplementary data}

Supplementary data to this article can be found online at http://dx. doi.org/10.1016/j.scitotenv.2013.12.059.

\section{References}

Abe Y, Aravena R, Zopfi J, Shouakar-Stash O, Cox E, Roberts JD, et al. Carbon and chlorine isotope fractionation during aerobic oxidation and reductive dechlorination of vinyl chloride and cis-1,2-dichloroethene. Environ Sci Technol 2009;43:101-7.

Aeppli C, Holmstrand H, Andersson P, Gustafsson O. Direct compound-specific stable chlorine isotope analysis of organic compounds with quadrupole GC/MS using standard isotope bracketing. Anal Chem 2010;82:420-6.

Audí-Miró C, Cretnik S, Otero N, Palau J, Shouakar-Stash O, Soler A, et al. Cl and C isotope analysis to assess the effectiveness of chlorinated ethene degradation by zero-valent iron: evidence from dual element and product isotope values. Appl Geochem 2013;32:175-83.

Bernstein A, Shouakar-Stash O, Ebert K, Laskov C, Hunkeler D, Jeannottat S, et al. Compound-specific chlorine isotope analysis: a comparison of gas chromatography/ isotope ratio mass spectrometry and gas chromatography/quadrupole mass spectrometry methods in an interlaboratory study. Anal Chem 2011;83:7624-34.

Blessing M, Schmidt TC, Dinkel R, Haderlein SB. Delineation of multiple chlorinated ethene sources in an industrialized area-a forensic field study using compoundspecific isotope analysis. Environ Sci Technol 2009;43:2701-7.

Bloom Y, Aravena R, Hunkeler D, Edwards E, Frape SK. Carbon isotope fractionation during microbial dechlorination of trichloroethene, cis-1,2-dichloroethene, and vinyl chloride: implications for assessment of natural attenuation. Environ Sci Technol 2000;34:2768-72.

Braeckevelt M, Fischer A, Kastner M. Field applicability of compound-specific isotope analysis (CSIA) for characterization and quantification of in situ contaminant degradation in aquifers. Appl Microbiol Biotechnol 2012;94:1401-21.

Christensen TH, Bjerg PL, Banwart SA, Jakobsen R, Heron G, Albrechtsen HJ. Characterization of redox conditions in groundwater contaminant plumes. J Contam Hydrol 2000;45:165-241.

Cichocka D, Siegert M, Imfeld G, Andert J, Beck K, Diekert G, et al. Factors controlling the carbon isotope fractionation of tetra- and trichloroethene during reductive dechlorination by Sulfurospirillum ssp. and Desulfitobacterium sp. strain PCE-S. FEMS Microbiol Ecol 2007;62:98-107.

Cichocka D, Imfeld G, Richnow HH, Nijenhuis I. Variability in microbial carbon isotope fractionation of tetra- and trichloroethene upon reductive dechlorination. Chemosphere 2008;71:639-48.

Darlington R, Lehmicke L, Andrachek RG, Freedman DL. Biotic and abiotic anaerobic transformations of trichloroethene and cis-1,2-dichloroethene in fractured sandstone. Environ Sci Technol 2008;42:4323-30.

Ertl S, Seibel F, Eichinger L, Frimmel FH, Kettrup A. The C-13/C-12 and H-2/H-1 ratios of trichloroethene, tetrachloroethene and their metabolites. Isot Environ Health Stud 1998;34:245-53.

Ferguson JF, Pietari JMH. Anaerobic transformations and bioremediation of chlorinated solvents. Environ Pollut 2000;107:209-15.

Hohener P, Atteia O. Multidimensional analytical models for isotope ratios in groundwater pollutant plumes of organic contaminants undergoing different biodegradation kinetics. Adv Water Resour 2010;33:740-51.

Huang L, Sturchio NC, Abrajano T, Heraty LJ, Holt BD. Carbon and chlorine isotope fractionation of chlorinated aliphatic hydrocarbons by evaporation. Org Geochem 1999;30:777-85.

Hunkeler D, Aravena R. Investigating the origin and fate of organic contaminants in groundwater using stable isotope analysis. In: Aelion CM, Hohëner P, Hunkeler D, Aravena R, editors. Environmental isotopes in biodegradation and bioremediation. Boca Raton: CRC Press; 2010. p. 249-93.

Hunkeler D, Chollet N, Pittet X, Aravena R, Cherry JA, Parker BL. Effect of source variability and transport processes on carbon isotope ratios of TCE and PCE in two sandy aquifers. J Contam Hydrol 2004;74:265-82.

Hunkeler D, Meckenstock RU, Sherwood Lollar B, Schmidt TC, Wilson JT. A guide for assessing biodegradation and source identification of organic ground water contaminants using compound specific isotope analysis (CSIA). Oklahoma: US EPA; 200859.

Hunkeler D, Van Breukelen BM, Elsner M. Modeling chlorine isotope trends during sequential transformation of chlorinated ethenes. Environ Sci Technol 2009;43:6750-6.

Hunkeler D, Abe Y, Broholm MM, Jeannottat S, Westergaard C, Jacobsen CS, et al. Assessing chlorinated ethene degradation in a large scale contaminant plume by dual carbon-chlorine isotope analysis and quantitative PCR. J Contam Hydrol 2011;119:69-79.

Jeannottat S, Hunkeler D. Chlorine and carbon isotopes fractionation during volatilization and diffusive transport of trichloroethene in the unsaturated zone. Environ Sci Technol 2012;46:3169-76.

Jeannottat S, Hunkeler D. Can soil gas VOCs be related to groundwater plumes based on their isotope signature? Environ Sci Technol 2013;47:12115-22.

Jendrzejewski N, Eggenkamp HGM, Coleman ML. Characterisation of chlorinated hydrocarbons from chlorine and carbon isotopic compositions: scope of application to environmental problems. Appl Geochem 2001;16:1021-31.

Lojkasek-Lima P, Aravena R, Parker BL, Cherry JA. Fingerprinting TCE in a bedrock aquifer using compound-specific isotope analysis. Ground water 2012a;50:754-64.

Lojkasek-Lima P, Aravena R, Shouakar-Stash O, Frape SK, Marchesi M, Fiorenza S, et al. Evaluating TCE abiotic and biotic degradation pathways in a permeable reactive barrier using compound specific isotope analysis. Ground Water Monit Remediat 2012b;32:53-62.

Numata M, Nakamura N, Koshikawa H, Terashima Y. Chlorine stable isotope measurements of chlorinated aliphatic hydrocarbons by thermal ionization mass spectrometry. Anal Chim Acta 2002:455:1-9.

Palau J, Soler A, Teixidor P, Aravena R. Compound-specific carbon isotope analysis of volatile organic compounds in water using solid-phase microextraction. J Chromatogr A 2007;1163:260-8. 
Pankow JF, Cherry JA. Dense chlorinated solvents and other DNAPLs in groundwater: history, behavior, and remediation. Portland, OR: Waterloo Press; 1996.

Pooley KE, Blessing M, Schmidt TC, Haderlein SB, Macquarrie KTB, Prommer H. Aerobic biodegradation of chlorinated ethenes in a fractured bedrock aquifer: quantitative assessment by compound-specific isotope analysis (CSIA) and reactive transport modeling. Environ Sci Technol 2009;43:7458-64.

Poulson SR, Drever JI. Stable isotope $(\mathrm{C}, \mathrm{Cl}$, and $\mathrm{H})$ fractionation during vaporization of trichloroethylene. Environ Sci Technol 1999;33:3689-94.

Sakaguchi-Soder K, Jager J, Grund H, Matthaus F, Schuth C. Monitoring and evaluation of dechlorination processes using compound-specific chlorine isotope analysis. Rapid Commun Mass Spectrom 2007;21:3077-84.

Shouakar-Stash O, Frape SK, Drimmie RJ. Stable hydrogen, carbon and chlorine isotope measurements of selected chlorinated organic solvents. J Contam Hydrol 2003;60: 211-28.

Shouakar-Stash O, Drimmie RJ, Zhang M, Frape SK. Compound-specific chlorine isotope ratios of TCE, PCE and DCE isomers by direct injection using CF-IRMS. Appl Geochem 2006;21:766-81.

Slater GF, Ahad JME, Lollar BS, Allen-King R, Sleep B. Carbon isotope effects resulting from equilibrium sorption of dissolved VOCs. Anal Chem 2000;72:5669-72.

Squillace PJ, Moran MJ, Lapham WW, Price CV, Clawges RM, Zogorski JS. Volatile organic compounds in untreated ambient groundwater of the United States, 1985-1995. Environ Sci Technol 1999;33:4176-87.
Thullner M, Centler F, Richnow HH, Fischer A. Quantification of organic pollutant degradation in contaminated aquifers using compound specific stable isotope analysis -review of recent developments. Org Geochem 2012;42:1440-60.

Van Acker MRMD, Shahar A, Young ED, Coleman ML. GC/multiple collector-ICPMS method for chlorine stable isotope analysis of chlorinated aliphatic hydrocarbons. Anal Chem 2006;78:4663-7.

Van Breukelen BM, Rolle M. Transverse hydrodynamic dispersion effects on isotope signals in groundwater chlorinated solvents' plumes. Environ Sci Technol 2012;46:7700-8.

Van Breukelen BM, Hunkeler D, Volkering F. Quantification of sequential chlorinated ethene degradation by use of a reactive transport model incorporating isotope fractionation. Environ Sci Technol 2005;39:4189-97.

Vroblesky DA, Rhodes LC, Robertson JF, Harrigan JA. Locating VOC contamination in a fractured-rock aquifer at the ground-water/surface-water interface using passive vapor collectors. Ground water 1996;34:223-30.

Wiedemeier TH. Natural attenuation of fuels and chlorinated solvents in the subsurface. New York: John Wiley; 1999.

Wiegert C, Aeppli C, Knowles T, Holmstrand H, Evershed R, Pancost RD, et al. Dual carbonchlorine stable isotope investigation of sources and fate of chlorinated ethenes in contaminated groundwater. Environ Sci Technol 2012;46:10918-25.

Wiegert C, Mandalakis M, Knowles T, Polymenakou PN, Aeppli C, Macháčková J, et al Carbon and chlorine isotope fractionation during microbial degradation of tetraand trichloroethene. Environ Sci Technol 2013;47:6449-56. 